\title{
States' Evolving Role in the Supplemental Nutritional Assistance Program
}

David A. Super

Georgetown University Law Center, das62@law.georgetown.edu

This paper can be downloaded free of charge from:

https://scholarship.law.georgetown.edu/facpub/2249

https://ssrn.com/abstract=3558186

David A. Super, States' Evolving Role in the Supplemental Nutritional Assistance Program, in Holes in the Safety Net: Federalism and Poverty (Ezra Rosser ed., Cambridge, U.K.: Cambridge University Press 2019)

This open-access article is brought to you by the Georgetown Law Library. Posted with permission of the author. Follow this and additional works at: https://scholarship.law.georgetown.edu/facpub

Part of the Administrative Law Commons, Law and Politics Commons, Legislation Commons, Social Welfare Law Commons, and the State and Local Government Law Commons 


\section{Holes in the Safety Net}

Federalism and Poverty

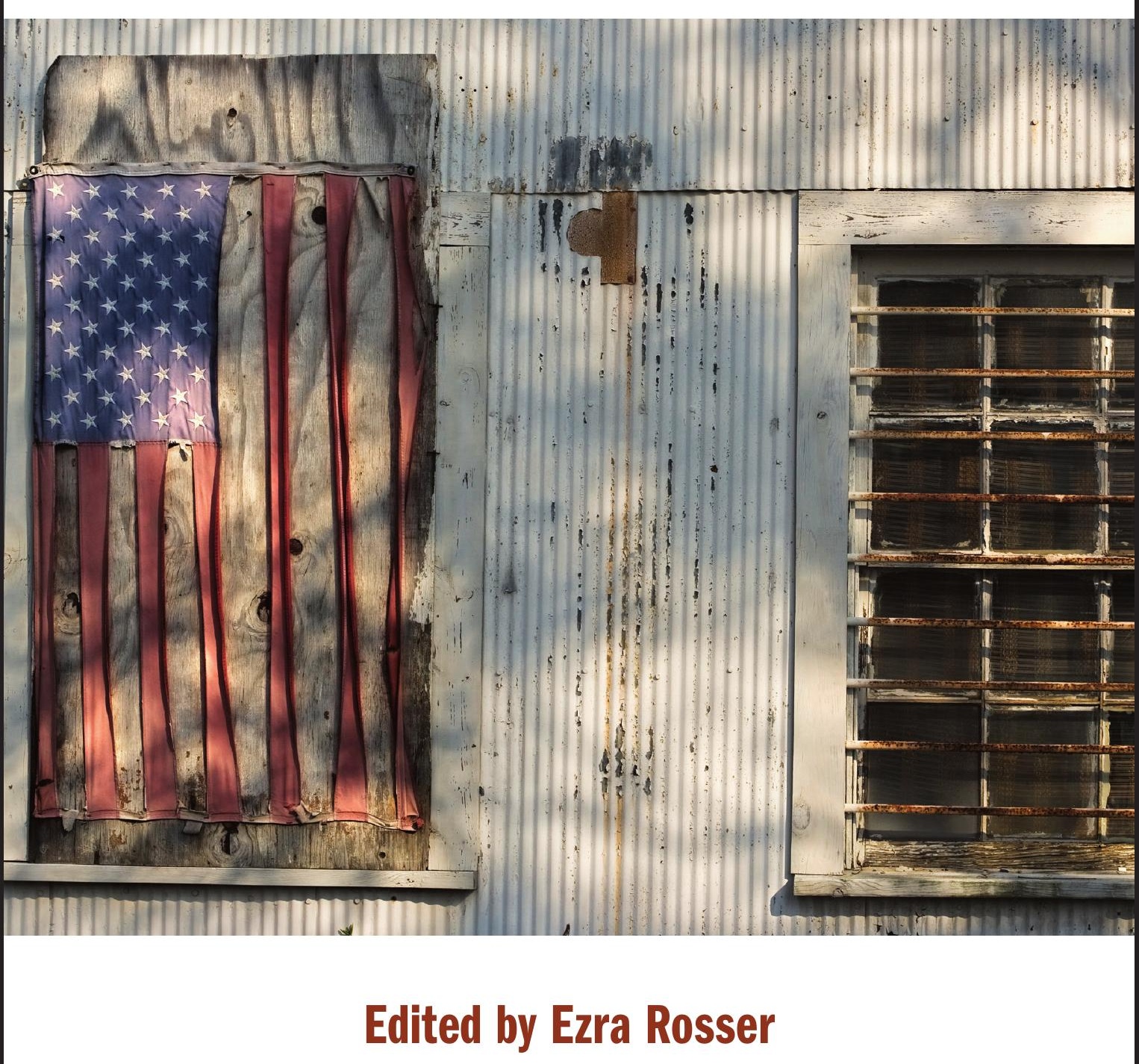




\section{HOLES IN THE SAFETY NET}

While the United States continues to recover from the 2008 Great Recession, the country still faces unprecedented inequality as increasing numbers of poor families struggle to get by with little assistance from the government. Holes in the Safety Net: Federalism and Poverty offers a grounded look at how states and the federal government provide assistance to poor people. With chapters covering everything from welfare reform to recent efforts by states to impose work requirements on Medicaid recipients, the book avoids unnecessary jargon and instead focuses on how programs operate in practice. This timely work should be read by anyone who cares about poverty, rising inequality, and the relationship between state, local, and federal levels of government.

Ezra Rosser is a law professor at American University Washington College of Law, where he teaches poverty law, property law, and federal Indian law. He is a co-author of the leading poverty law textbook and is the editor of the Poverty Law Blog. 


\title{
Holes in the Safety Net
}

\author{
FEDERALISM AND POVERTY
}

\author{
Edited by \\ EZRA ROSSER \\ American University Washington College of Law
}




\section{CAMBRIDGE UNIVERSITY PRESS}

University Printing House, Cambridge св2 8вs, United Kingdom

One Liberty Plaza, 2oth Floor, New York, NY 10006, USA

477 Williamstown Road, Port Melbourne, vIC 3207, Australia

314-321, 3rd Floor, Plot 3, Splendor Forum, Jasola District Centre, New Delhi - 110025, India

79 Anson Road, \#o6-04/o6, Singapore 079906

Cambridge University Press is part of the University of Cambridge.

It furthers the University's mission by disseminating knowledge in the pursuit of education, learning, and research at the highest international levels of excellence.

www.cambridge.org

Information on this title: www.cambridge.org/9781108475730

DOI: $10.1017 / 9781108631662$

(C) Cambridge University Press 2019

This publication is in copyright. Subject to statutory exception and to the provisions of relevant collective licensing agreements, no reproduction of any part may take place without the written permission of Cambridge University Press.

First published 2019

Printed and bound in Great Britain by Clays Ltd, Elcograf S.p.A.

A catalogue record for this publication is available from the British Library.

Library of Congress Cataloging-in-Publication Data

NAMES: Rosser, Ezra, editor.

TITLE: Holes in the safety net : federalism and poverty / edited by Ezra Rosser.

DESCRIPTION: 1 Edition. | New York : Cambridge University Press, 2019. |

Includes bibliographical references and index.

IDENTIFIERS: LCCN 2018058442 | ISBN 9781108475730 (hardback) | ISBN 9781108468848 (paperback) subjects: LCSh: Public welfare-United States. | Poverty-Government policy-United States. |

Legal assistance to the poor-United States. | Federal government-United States. |

State governments-United States. | BISAC: LAW / Constitutional.

CLASSIFICATION: LCC HV95 .H625 2019 | DDC 362.5/560973-dc23

LC record available at https://ccn.loc.gov/2018058442

ISBN 978-1-108-47573-0 Hardback

Cambridge University Press has no responsibility for the persistence or accuracy

of URLs for external or third-party internet websites referred to in this publication and does not guarantee that any content on such websites is, or will remain, accurate or appropriate. 


\section{Contents}

Introduction

Ezra Rosser

PART I: WELFARE AND FEDERALISM

$1 \quad$ Federalism, Entitlement, and Punishment across the US Social Welfare State Wendy Bach

2 Laboratories of Suffering: Toward Democratic Welfare Governance Monica Bell, Andrea Taverna, Dhruv Aggarwal, and Isra Syed

3 The Difference in Being Poor in Red States versus Blue States Michele Gilman

PART II: STATES, FEDERALISM, AND ANTIPOVERTY EFFORTS

4 States' Rights and State Wrongs: Supplemental Nutritional Assistance Program Work Requirements in Rural America Rebecca H. Williams and Lisa R. Pruitt

$5 \quad$ State and Local Tax Takeaways

Francine J. Lipman

6 Early Childhood Development and the Replication of Poverty

Clare Huntington 
7 States Diverting Funds from the Poor

Daniel Hatcher

8 States' Evolving Role in the Supplemental Nutritional

Assistance Program

David A. Super

PART III: ADVOCACY

195

9 Federalism in Health Care Reform

Nicole Huberfeld

10 Poverty Lawyering in the States

215

Andrew Hammond

11 Conclusion: A Way Forward

Peter Edelman

Index

255 


\title{
States' Evolving Role in the Supplemental Nutritional Assistance Program
}

\author{
David A. Super
}

\section{INTRODUCTION}

States have always been crucial to the Supplemental Nutrition Assistance Program (SNAP, formerly food stamps). ${ }^{1}$ Even though the federal government has paid virtually all the program's benefit costs, state administration has always been indispensable for several reasons. State and local governments pay their staff considerably less than the federal government, making state administration less expensive. ${ }^{2}$ States already administer other important antipoverty programs, notably family cash assistance and Medicaid, allowing them to coordinate the programs and minimize repetitive activities. And states have somewhat lower, and less polarizing, political footprints than does the federal government, moderating criticism of the program. In addition, giving states a stake in SNAP's administration often has co-opted them to support, or at least avoid attacking, the program.

From the perspective of states, administering SNAP has been an attractive deal. Even though federal merit systems' requirements prevent states from using SNAP administrative positions for patronage, getting a large number of state workers at only half the net cost is an attractive proposition. No doubt significant numbers of households mistakenly believe that the benefits they receive come from the state's coffers when they receive them through state offices. And because the Food and Nutrition Act makes no provision for anyone other than states to administer SNAP, a state's refusal to do so would mean turning away hundreds of millions or billions of dollars of federal funds and straining local charities far past the breaking point.

States' entrenched administrative role in SNAP has given them enormous influence over how the program operates. Some of this power comes directly from their

1 Throughout this chapter, I will refer to SNAP and the Food and Nutrition Act of 2008 when speaking about all periods, even those when benefits were called food stamps and were issued under the Food Stamp Acts of 1964 or 1977.

$=$ David A. Super, Rethinking Fiscal Federalism, 118 Harv. L. Rev. 2544, 2567 (2005). 
role as administrators. The oft-repeated claim that SNAP is a program controlled entirely by federal law has never been true. Over time, states' control over program operations has shifted somewhat from covert means to overt state options, but a major state influence has remained. Anyone who follows the program nationally can tell you in which states they would, or would not, prefer to live if they needed SNAP.

States also have exerted considerable influence over the program on the federal level. Much of the program's durability has come from its ability to transcend partisan politics with a culture of objective policy analysis. This culture derives in part from the peculiar nature of the US Department of Agriculture (USDA) and the House and Senate Agriculture Committees, which are deeply conservative but also dependent on the broader Congress to continue programs that transfer resources from taxpayers and consumers to agribusiness. Analytically defensible SNAP policy burnishes the image of the USDA and the committees as responsible stewards. Carrying out this mission have been a relatively pragmatic series of chairs and ranking members of the nutrition subcommittees and a career staff at the Food and Nutrition Service (FNS) that is deeply committed to professionalism. State human services agencies provided an obvious talent pool of public administrators knowledgeable about SNAP. These officials brought their appreciation of front-line administrative challenges, and their contacts with people still in state agencies, when they joined the federal service.

State human services agencies also have been a major source of the bureaucratic expertise on which federal policy makers have relied. Because of their official role implementing the program, federal officials and congressional staff routinely hold meetings with states' representatives from which other stakeholders are excluded. The policy decisions emanating from such meetings are all but impossible to dislodge. When antihunger advocates criticize conservative proposals, or right-wing groups attack liberal ones, state officials often hold the de facto deciding voice, adjudicating the claims for federal political officials less steeped in policy details. Savvy advocates learn to approach state agency representatives first with any proposals for federal policy change: if the states uniformly hate it, the proposal is probably dead, and if the states have concerns the advocates need to build a preemptive response into their initial pitches to federal administrators or congressional staff. State agencies have sufficient means of making federal administrators' lives difficult that FNS will often bow to states even on issues where it disagrees. And state human services officials' presumed expertise allows them unusual political access across the partisan divide even in times of increasing polarization: even if a senator is thoroughly estranged from her or his opposite-party governor, the state's SNAP director - who, of course, works for that governor - can readily get through.

Knowing that states have broad influence over SNAP does not tell us how they will exercise that influence. The values states seek to maximize in their influence on SNAP have shifted considerably over time in response both to general political, social, and economic currents and to changes in the program itself. Only rarely have 
they functioned as true laboratories of democracy with respect to SNAP, pursuing varying courses toward a common end.

States' SNAP agendas reflect the shifting influence and priorities among four main groups. ${ }^{3}$ First, employers have sought a disciplined labor force. If SNAP is too generous, workers may decline onerous low-wage jobs. If it is too miserly during periods when employment is unavailable, the workers might move away and shrink the available labor pool. These employer interests were particularly important, especially in agricultural areas, during the program's early years. As agriculture automated and the national economy developed away from mass employment of low-skilled workers, these concerns faded away from SNAP policy discourse. They appear to be making a strong comeback in recent years, although the new emphasis on workforce discipline represents something quite different.

Second, a wide range of humanitarians support SNAP as a means of meeting one of the most basic of human needs. Some of these are simply compassionate voters with no particular connection to hungry people. Others may be involved in religious or other charity work and recognize that their efforts cannot scratch the surface in meeting peoples' needs without the nutritional foundation that SNAP provides. Organizations of low-income people played important roles in some states despite considerable barriers to their exercising political power. ${ }^{4}$ State legislators from districts with large numbers of low-income people can be important voices for strengthening SNAP. Particularly in rural areas, these often include Republicans. Labor unions representing low-skilled workers have supported SNAP as a means of reducing employers' leverage, although labor interest waned rapidly after Congress excluded most strikers from SNAP in the late 1970s. Often humanitarians are found inside state human services agencies. Public employee unions have strongly supported SNAP. On the managerial level, SNAP directors often are among the most liberal senior executives inside state human services agencies: people with undeniable skills but too much empathy for low-income people to be placed in charge of programs dispensing state-funded benefits such as Medicaid.

A third, more diffuse, group that periodically influences state SNAP policy consists of efficiency-oriented economic elites. Businesses and affluent individuals seek lower state taxes, causing them to favor policies that maximize federal funding: a less-generous SNAP would increase pressure for state-funded programs to fill the gaps. Many businesses see low-income people more as a market than as a potential workforce. The more SNAP covers households' food needs, the more cash they have to pay their rent and utility bills and to buy other items. To the extent that these elites see low-income people as workers, they may regard SNAP benefits as lowering wage demands much as employers welcome the Earned Income Tax Credit (EITC)

3 See David A. Super, Laboratories of Destitution: Democratic Experimentalism and the Failure of Anti-Poverty Law, 157 U. PA. L. Rev. 541, 593-600 (2008).

4 David A. Super, Protecting Civil Rights in the Shadows, 123 YaLE L. J. 2806 (2014). 
as reducing workers' reservation wage. SNAP's financing makes these elites natural supporters of the program - as long as their frame of reference is state specific.

A fourth group whose influence on state SNAP policies has grown dramatically over time has been ideologues seeking new battlegrounds. For them, state SNAP policy is more expressive than practical. Often, they seek to extend federal battles, especially during periods when federal policy is gridlocked. Initially, the most significant of these groups were on the left. More recently, a vast increase in rightwing funding, much of it coordinated by the American Legislative Exchange Council (ALEC), has led to a proliferation of state-facing organizations deeply hostile to SNAP.

This chapter charts the history of states' roles in SNAP as administrators, policy makers, and policy advocates on the federal level. It finds that shifts in the strengths and priorities of some of these groups, and in the emphasis each of them places on SNAP, have produced dramatic changes in state policies.

\section{STATES AS DISCIPLINARIANS OF THE POOR}

During the modern SNAP's earliest years, ${ }^{5}$ the dominant policy model cast the states as disciplinarians of low-income people. Prior to one person, one vote, rural interests had outsized influence in state legislatures and were determined to prevent anything from diminishing farm and domestic workers' willingness to accept low wages. These attitudes contributed to the consistent parsimony of states' grant levels and eligibility rules in Aid to Dependent Children and later Aid to Families with Dependent Children (AFDC). The depth of this concern was evident in many states' decisions to set SNAP eligibility and benefit levels lower than permitted under federal law even though it would have cost the states nothing to provide benefits up to the federally defined level.

Aware of rural communities' antipathy for antipoverty programs, when Congress and President Nixon sought to make SNAP a national program in the early 1970 s $^{6}$ they required that states participate statewide or not at all. By then, urban areas had developed sufficient political power, and areas already operating SNAP had seen enough of its benefits, that giving up the program to accommodate recalcitrant rural areas was unlikely. Still, several states had tense battles over statewide implementation of SNAP, and a few saw litigation. ${ }^{7}$ A compromise in some states was to give counties primary administrative responsibility, with broad state oversight. Counties

5 An earlier version of the Food Stamp Program existed during the Great Depression. It was sufficiently remote (temporally and politically) from the modern program, which began with pilot projects in 1963 and federal legislation in 1964 that lessons from it are not readily transferrable.

6 Pub. L. No. 93-86, 87 Stat 221 (1973).

7 Madden v. Oklahoma, 523 F.2d 1047 (10th Cir. 1975); Commw. Dep't of Public Welfare v. Adams County, 392 A.2d 692 (Pa. 1978). 
also won the right to establish SNAP workfare programs even over their state's objections.

The modern SNAP was established in the midst of the civil rights revolution, at a time when states' rights were widely seen as a vehicle for perpetuating segregation and oppression. Accordingly, it had relatively strong civil rights protections earlier than other federal-state benefit programs. Distrusting exercises in discretion that state and local human services agencies had manipulated to disadvantage people of color, FNS began the development of highly specific substantive and procedural rules, initially contained in an FNS manual. Congress added far more detail to the federal statute in $1977,{ }^{8}$ and FNS took that opportunity to promulgate a detailed set of federal regulations after holding numerous hearings around the country to solicit information on problems in the program's current operations. ${ }^{9}$

Having standards is one thing, of course, but enforcing them is another. Federal statutes appeared to give FNS substantial leverage on noncompliant state and local agencies. In practice, however, each of the available tools was problematic. The Secretary of Agriculture could ask the Attorney General to sue a state for injunctive relief; ${ }^{10}$ in practice, this has never happened as the rupture in federal-state relations that such a suit would bring has struck FNS as too drastic. FNS has the authority to withhold federal administrative funding from a noncompliant state. ${ }^{11} \mathrm{FNS}$, however, has consistently believed states are spending too little on administering SNAP; reducing administrative resources further, especially for acts of nonfeasance, was unappealing. Moreover, creating a large hole in the state's human services budget could get the SNAP director fired - whether she or he was responsible for the problem - potentially putting the state's program in inexperienced hands at a time of crisis. Accordingly, FNS established an elaborate system of warnings designed to get the attention of officials senior enough to command the necessary resources to address the problem without destabilizing SNAP in the state. Even when FNS did withhold funds, it typically restored them once the state came into compliance. Because this bluff becomes less effective the more often it is run, FNS was hesitant to make formal findings of state noncompliance.

Simultaneously, however, private enforcement was becoming a realistic possibility. The Supreme Court's embrace of relatively liberal standards for private enforceability of programmatic statutes, together with the survival and growth of federally funded civil legal services, gave low-income households the chance to hold state and local agencies accountable for discriminatory, belligerent, or incompetent administration of SNAP. Coordinating much of this effort was the Food Research and Action Center (FRAC), a nonprofit group led by creative and energetic litigators

\footnotetext{
8 Food Stamp Act of 1977, Pub. L. No. 95-464 (1977).

97 C.F.R. Parts 271-290 (2018).

${ }^{10} 7$ U.S.C. $\int 2020(\mathrm{~g})(2016) ; 7$ C.F.R. $\int 276.5$ (2018).

117 U.S.C. $\int 2020(\mathrm{~g})(2016) ; 7$ C.F.R. $\int 276.4(2018)$.
} 
who saw access to food assistance as the next front in the civil rights movement. ${ }^{12}$ Lawsuits FRAC brought or helped to coordinate challenged access to the program, ${ }^{13}$ delays in state application processing, ${ }^{14}$ the lack of prompt, effective fair hearings, ${ }^{15}$ and the failure to pay retroactive benefits to households unlawfully denied assistance. $^{16}$

The decline in power and commitment by employer groups seeking a dependent low-skill workforce, the promulgation of detailed regulations facilitating comparison of state and local offices' administration of the program, and the threat of recipient litigation and occasional federal sanctions pushed the disciplinarian model of state administration to the margins. A few traces of it remain. A handful of counties scattered around the country continued to operate workfare programs. Underfunding still led to periodic administrative problems, and the considerable discretion SNAP offices had in how much paperwork to demand of applicants likely led to significantly disparate experiences for households in different parts of the country.

Disciplinarian themes appeared in federal policy discourse when most strikers were ejected from the program in the late $1970 \mathrm{~s}^{17}$ and when Senator Jesse Helms won adoption of an employment and training (E\&T) program for SNAP recipients in $19855^{18}$ The American Enterprise Institute's Charles Murray had tried to revive idea of disciplining the poor a year earlier when he proposed abolishing all antipoverty programs operating above the county level, with the idea that local officials would have a better sense of the availability of work for claimants. ${ }^{19}$ His work triggered a hail of criticism over his misuse of crucial data ${ }^{\circ}{ }^{\circ}$ although he became an instant icon on the ideological right, his ideas had little immediate impact on policy.

It was a sign that the times had changed, however, when state SNAP administrators objected to the required high participation rates and low funding that E\&T initially featured. In response to these complaints and an FNS study showing that E\&T had no positive effects on employment or wages ${ }^{21}$ Congress moderated those participation rate requirements in the early 1990s. With their own experience of

12 The author served as FRAC's legal director, albeit many years after the heyday of its litigation role.

13 E.g., Tyson v. Maher, 523 F.2d 972 (2d Cir. 1975).

14 E.g., Aiken v. Obledo, 442 F. Supp. 628 (E.D. Cal. 1977).

${ }^{15}$ E.g., Lambus v. Walsh, $44^{8}$ F. Supp. 240 (W.D. Mo. 1978).

16 E.g., Bermudez v. USDA, 490 F.2d 718 (D.C. Cir. 1973); Carter v. Butz, 479 F.2d 1084 (3d Cir. 1973).

${ }^{17} 7$ U.S.C. $\$ 2015(\mathrm{~d})(3)(2016)$.

${ }_{18} 7$ U.S.C. $\$ 2015(\mathrm{~d})(4)(2016)$.

19 Charles Murray, Losing Ground American Social Policy 1950-1980 227-33 (1984).

${ }^{20}$ See, e.g., Robert Greenstein, Losing Faith in "Losing Ground," New Republic, Mar. 25, 1985 , at 12 .

${ }^{21}$ Michael J. Puma et al., Food \& Nutrition Serv., Evaluation of the Food Stamp Employment and Training Program: Final Report (June 1990). 
E\&T's uselessness mirroring research findings, few states claimed much of the openended federal matching funds available to expand their E\&T programs.

\section{STATES AS MAXIMIZERS OF FEDERAL FUNDING}

From the early 196os to the 1980s, the value of low-income families' combined AFDC and SNAP benefits remained roughly constant after adjusting for inflation. This occurred because the creation and expansion of SNAP roughly offset the stagnation of AFDC eligibility and benefit levels. SNAP eligibility and benefit levels were tied, directly or indirectly, to the federal poverty level, which rose with inflation. Few states automatically adjusted their AFDC eligibility or grant levels for inflation, and many states would freeze or cut grant levels during the fiscal crises that accompanied recessions.

One effect of this shift in the composition of a roughly constant benefit package was a transfer of resources from the federal government, which paid all SNAP benefit costs, to states, which paid for 20-30 percent of AFDC benefits. This also led many state governments to start seeing SNAP as an important infusion of federal dollars into their local economies. A decade or so before Medicaid "creative financing" schemes began siphoning billions of addition dollars into state coffers, ${ }^{22}$ a more low-key change began to emerge in state attitudes toward SNAP.

The evolving resource-maximizing view of SNAP manifested itself in a range of ways, some crudely self-interested. Many states cut, or failed to increase, AFDC benefits $^{23}$ in reliance on SNAP to offset 30-45 percent of the loss to households. ${ }^{24}$ Other states went further and sought waivers from federal law to convert SNAP benefits into cash to make them full substitutes for partially state-funded cash assistance. After the Clinton administration showed no willingness to deny such waivers, a coalition of alarmed liberal and agriculture-oriented members of Congress enacted first an appropriations rider prohibiting new cash-out waivers and then made the restriction permanent with a provision in the 1996 welfare law. ${ }^{25}$

Most states, however, took a broader view of maximizing federal funds, seeking to increase SNAP benefits for their residents rather than seeking to directly fill state coffers. Several redesignated portions of cash assistance grants in ways that could

22 David A. Super, Public Welfare Law 783-84 (Foundation Press 2016).

${ }_{23}$ See, e.g., Quattlebaum v. Barry, 671 A.2d 881 (D.C. 1995) (finding this explicit reliance did not violate 7 U.S.C. $\$ 2017$ (b), which prohibits considering SNAP benefits in determining eligibility for other public program).

24 SNAP benefits generally rise 30 cents for each dollar reduction in net income. 7 U.S.C. \& 2017 (a) (2016). Net income for households with high shelter costs, however, is calculated with a deduction that grows as income declines, leaving many households with an effective marginal benefit reduction rate of 45 percent for unearned income such as AFDC benefits. See id. $\$ 2014$ (d)(6).

257 U.S.C. $\int 2026(\mathrm{~b})(\mathrm{I})(\mathrm{B})(\mathrm{iv})(\mathrm{I})$ and (II) (2016). 
prevent them from being counted as income in SNAP, thus increasing SNAP benefits. ${ }^{26}$ Some sued USDA for permission to apply more lenient income-counting rules in determining SNAP benefits. ${ }^{27}$ A dozen states quietly refused to follow FNS's policy of counting utility allowances from public housing authorities as income to resident households, while recipients and one state litigated the matter, prevailing after more than a decade. ${ }^{28}$ With state human services agencies' encouragement, many members of Congress come to regard SNAP like other grants in aid, advocating policies that would send more money to their home states. ${ }^{29}$

Remarkably in light of subsequent events, states overwhelmingly opposed proposals by President Reagan and Senator Helms to convert SNAP into a block grant to the states. Although particular state officials would have gained more control over federal benefit dollars, they recognized that block grant funding would deteriorate over time to leave low-income households with less ability to purchase food absent increased state funding. Even in the more polarized environment of the mid-199os, most governors and almost all state administrators expressed little or no support for proposals to block-grant SNAP even as they were eagerly lobbying to replace AFDC.

The most important manifestation of the benefit-maximizing mindset, however, appeared in states' exercise of discretion in program administration. More and more state human services agencies began to signal their front-line eligibility workers to be more lenient in granting SNAP benefits than they were for state-funded benefits. Deep-seated hostilities toward low-income people nurtured by some eligibility workers limited these signals' effectiveness, but overall SNAP became significantly more accessible, increasing participation.

Under other circumstances this shift might have gone unnoticed, but the late 1970s saw two other forces driving up SNAP participation: the recession of 1979-80 and the Food Stamp Act of 1977, which opened the program to many more lowwage workers and made participation more attractive by eliminating the

${ }^{26}$ See, e.g., Maryland Dep't of Human Services v. USDA, 976 F.2d 1462 (4th Cir. 1992) (discrediting one state's purported energy assistance program); Comm. on Ways \& Means, U.S. House of Representatives, Comm. on Ways \& Means, 1994 Green Book 367 n. 5 (describing nine states' designation of parts of AFDC grants as energy assistance); Commw. of Mass. v. Lyng, 893 F.2d 424 (1st Cir. 1990) (refusing to exclude back-to-school clothing allowances from SNAP income).

${ }^{27}$ See, e.g., id.; Dep't of Health \& Welfare, State of Idaho v. Block, 784 F.2d 895 (9th Cir. 1986) (finding energy assistance recipients entitled to standard utility allowance in computing SNAP shelter deduction); State of New York v. Lyng, 829 F.2d 346 (2d Cir. 1987) (declining to exclude from SNAP income allowances given to homeless people to allow them to obtain meals in restaurants); South Dakota Dep't of Social Serv. v. Madigan, 824 F. Supp. 1469 (D.S.D. 1993) (finding that public housing utility allowances do not count as income in determining SNAP benefits).

${ }^{28}$ See Estey v. Comm'r, Maine Dep't of Human Serv., 21 F.3d 1198 (1st Cir. 1994) (finding utility allowances excludable); West v. Bowen, 879 F.2d 1122 (3d Cir. 1989) (same).

29 For example, Senate Agriculture Committee Ranking Republican Richard Lugar inserted 7 U.S.C. $\int 2014(\mathrm{k})(2)(\mathrm{G})$ into the statute to exclude from SNAP income calculations township relief payments of a type found in his home state of Indiana. 
requirement that households purchase (at a discount) their benefits. With SNAP operating under a funding cap, surging participation forced the Carter administration to make an embarrassing request for emergency legislation to keep benefits flowing. ${ }^{30}$ In response to harsh congressional questioning about the surge in participation, the administration inaugurated an auditing system known as quality control (QC).

Although the Carter administration envisioned QC as one of many management tools to identify states' administrative deficiencies, when Ronald Reagan took over the White House and Republicans won control of the Senate, it quickly became much, much more. President Reagan and new Senate Agriculture Committee Chair Jesse Helms established severe automatic fiscal penalties for any state whose error rate exceeded 5 percent, as measured by QC's methods of imputation from a random sample. This level was dramatically lower than almost any state was achieving. Once the new system became fully effective with federal fiscal year 1983 , more than 45 states faced sanctions each year. The amounts of these sanctions were staggering, far beyond most states' ability to absorb without action from their legislatures and likely deep cuts to their staffing levels. This presented the same dilemma that FNS had always faced concerning fiscal sanctions against states: if the state needed more, not less administrative resources, slashing its human services budget would only make matters worse. Here, however, FNS had far less room to maneuver: it was having to deal with the great majority of states all at once, the amounts at issue were generally much greater than FNS had even threatened on its own, no simple path to state compliance was evident, the statute gave the agency little discretion, and it was under immense pressure from Senator Helms, the Reagan White House, and its own political leadership (including former Helms staffer John Bode as Assistant Secretary) to take a hard line.

The Reagan administration's political leadership placed enormous pressure on FNS to reduce error rates, which in turn led many FNS regional offices to place enormous pressure on human services administrators. Previously cordial quarterly meetings between FNS Regional Administrators and state human services commissioners became tense standoffs over error rates. Accustomed to federal demands to implement this or that required SNAP policy, states were frustrated that FNS refused to specify what actions states could take to satisfy it. FNS insisted that only radically lower error rates would suffice. As SNAP directors and human services commissioners made their governors and legislatures aware of these potential sanctions, states' attitudes toward SNAP began to change. Several liberal SNAP directors and welfare commissioners were fired over QC error rates despite the fact that the vast majority of other states were in the same position. Some states concluded that SNAP expertise was crucial to solving a SNAP problem and promoted career civil servants with

30 See David A. Super, The Political Economy of Entitlement, 104 Colum. L. Rev. 633 (2004) (describing drawbacks of funding caps). 
commitments to low-income people not very different from those of their predecessors; others sought the sort of dispassionate accounting-oriented managers that had for some time run their Medicaid programs.

States' messages to front-line eligibility workers changed dramatically. Verification requirements multiplied, with those unable to produce the demanded documents summarily denied SNAP. These policies made accessing SNAP exceedingly difficult for people who have difficulty preserving important documents because of frequent moves, family breakups, or criminal victimization. The move to maximum verification was particularly ill-timed as the recession of 1981-82, deinstitutionalization, and the evisceration of state general assistance programs was creating a surge in homelessness.

Because the QC error rates that determined fiscal sanctions depended exclusively on improper awards of benefits and overissuances - not improper denials or underissuances - many states began to send eligibility workers' ill-disguised messages that, when in doubt, they should deny SNAP benefits. Indeed, because in a large portion of error cases the agency acted correctly given what it knew at the time, many eligibility workers came to view all applicants and recipients as potential sources of errors. Some states found creative means of driving home the single-mindedness of their demand for avoiding errors, frequently imposing collective punishment on local offices with high error rates even though QC samples were insufficient to generate reliable county-level estimates. One state required eligibility workers who had had cases containing QC errors to post pictures of bombs in their cubicles so that their colleagues could see who was responsible for the office's error rate. ${ }^{31}$

At the same time, Congress required states to compel almost all SNAP households to submit monthly reports on their circumstances whether anything had changed. The window for submitting these reports was extremely narrow: reports submitted too early were deemed incomplete and those submitted more than a few days after the end of the prior month were deemed late, in either case resulting in a suspension of benefits. If an eligibility worker was behind on paperwork or on vacation, if the SNAP office's mail sorting and distribution malfunctioned, or if its automated system failed, households that had complied perfectly were cut off, ${ }^{32}$ without a pretermination hearing. ${ }^{33}$ QC gave local SNAP managers an unappealing choice when they lacked the staff to process monthly reports timely: suspending the benefits of households that reported timely would be unlawful, but continuing benefits when some of their reports might contain changes that should affect their benefit level invited QC errors that could cost the manager her or his job.

${ }^{31}$ A scarlet "QC" might have been more fitting.

32 Robert Greenstein \& Marion E. Nichols, Ctr. on Budget \& Pol’y Priorities, Monthly Reporting in the Food Stamp Program (Sept. 1988).

337 C.F.R. $\int 273.21(h)(2018)$. 
Unsurprisingly, procedural terminations of eligible households proliferated. ${ }^{34}$ States were required to report their rates of improper denials, but FNS generally did not audit those claims. The Government Accountability Office (GAO) and other outside groups found serious underreporting of improper denials. ${ }^{35}$ FNS's response was tepid at best compared with the relentless campaign to lower error rates. Eventually, many antihunger advocates at both the federal and state levels concluded that lightening QC's heavy hand on state administration was the most important change that could be made in SNAP, ahead of liberalizations in eligibility and benefit computation rules.

QC dominated federal-state relations concerning SNAP for almost two decades. It sharply changed the nature of states' maximizing behavior from concern about the budgets of low-income households to fretting about their own. It also marginalized the threat of litigation by low-income households to enforce provisions of the federal statute and regulations: even if such litigation were to go badly, the sanctions a court might plausibly impose would pale compared to QC penalties. ${ }^{36}$

By the late 1980s, QC politics had begun to change at the federal level. More and more states had concluded that existing targets were essentially unmeetable, focusing their attention on federal legislation. Covington \& Burling, which represented many states in litigating QC penalties, strongly urged its clients to pursue a legislative solution and represented them in that process. Several former governors and state legislators who had confronted QC sanctions had entered Congress. The two most powerful organizations of state governments - the National Governors Association and the National Conference of State Legislatures - heard concern from such a broad cross-section of states that they moved SNAP QC to the top of their legislative priorities.

On the other side, Senator Helms almost completely disengaged from SNAP when he lost the chair of the Agriculture Committee after Democrats won the Senate in 1986; indeed, he elected to displace Richard Lugar as the ranking member on the Foreign Relations Committee, which made it awkward for him to interfere in Senator Lugar's leadership on the Agriculture Committee. Assistant Secretary Bode and other USDA officials appeared to have wearied over fighting with states about QC. QC error rates had declined sharply, weakening the political imperatives that had led Congress to impose automatic sanctions. By this time, the only major active participant in SNAP policy making who did not seek to dial back QC sanctions was the Office of Management and Budget's (OMB's) poetically named budget

34 See, e.g., Anna Lou Dehavenon, Charles Dickens Meets Franz Kafka: The Maladministration of New York City's Public Assistance Programs, 17 N.Y.U. Rev. Law \& Soc. Change 231 (198990)

35 See, e.g., GaO, Food Stamp Program: Evaluation of Improper Denial or Termination Error Rates (1987). At the time, GAO was known as the General Accounting Office.

${ }^{6}$ David A. Super, Are Rights Efficient? Challenging the Managerial Critique of Individual Rights, 93 Calif. L. Rev. 1051 (2005). 
examiner for SNAP, Les Cash. Although personally sympathetic to SNAP's goals, Cash understood OMB's institutional role as maintaining relentless pressure for better program administration. Many at OMB then also saw it as an institutional counterweight to cabinet departments and Congress, both of which are susceptible to capture by state governmental interests.

After protracted negotiations among states, Bode, and antihunger advocates, with congressional staff of both parties acting as mediators and Cash unseen but closely constraining what Bode could offer, a substantial revision of SNAP QC was added to the Hunger Prevention Act of $1988^{37}$ that sought to cut in half the number of states sanctioned each year. It also added underissuances to recipients - but not the far more important improper denials - to error rate calculations. For budgetary reasons, however, it did not address the huge backlog of sanctions states had accrued up to that point.

After President George H. W. Bush lost the 1992 election, and most of his political appointees with responsibility for SNAP left for private-sector jobs, Andrew Hornsby, the former Alabama welfare commissioner, became acting FNS Administrator. Hornsby concluded that the risk of accusations of fiscal irresponsibility, and the watchful eye of $\mathrm{OMB}$, would deter any regular presidential appointee from eliminating the huge backlog of state QC sanctions. Accordingly, he offered to excuse 85 percent of states' outstanding sanction balances in exchange for promises to "reinvest" the remaining 15 percent in efforts to improve state administration. States took him up on his offer en masse. A series of legislative and further executive actions eliminated or sharply reduced sanction liabilities for subsequent years. Antihunger legislation in $1993^{3^{8}}$ further modified SNAP QC, sharply reducing penalty amounts by scaling them to the severity of violations but somewhat increasing the number of states sanctioned.

Although QC was no longer sanctioning 45 states a year, it was still sanctioning about half of them each year; many more were within or near the QC sample's margin of error. Only about 10 states each year could be confident that they would not face sanctions, with the rest continuing to obsess about their error rates. At the opening sessions of the American Association of SNAP Directors, where state delegations introduce themselves and talk briefly about the issues dominating their attention, almost every state discussed its error rate and typically nothing else.

While most antipoverty advocates were distracted by congressional battles over the 1996 welfare law, states and FNS career staff quietly began transforming SNAP in response to QC pressures. Given the pressure it was applying to state administrators, FNS felt uncomfortable refusing states' proposals to change SNAP rules in ways that might allow them to reduce errors. FNS therefore began granting waivers from some access-protecting regulations and abandoned enforcement of others. This allowed

$3^{8}$ Omnibus Budget Reconciliation Act of 1993, Pub. L. No. 103-624 (1993). 
states more leeway to deny or terminate eligible households for minor technical mistakes. It also let states require households to reapply every three months to continue receiving benefits. Neither FNS nor the states explained how this squared with regulations requiring states to grant households the longest possible certification period up to one year and prohibiting certification periods less than six months absent extraordinary circumstances. ${ }^{39}$

The impact of these practices was concealed initially by caseload declines driven by an improving economy, the stigmatizing effect of debates over what became the 1996 welfare law, and the massive SNAP cuts that law contained. By 1998, however, the Center on Budget and Policy Priorities noticed that caseload declines were about twice what could be explained by the improving economy and the estimated impact of the welfare law. ${ }^{40}$ Further, as more data became available it emerged that caseload declines were much steeper in two heavily overlapping groups of states: those achieving very large reductions in their QC error rates and those dramatically increasing their reliance on three-month certification periods. Flying in the face of the "welfare-to-work" rhetoric dominating human services debates in that period, these caseload reductions fell heaviest on working families with children. This reflected states' belief that these households had the greatest risk of causing QC errors because of the potential for their circumstances to change without the state agency learning and acting in time to adjust the household's benefits. In a clear faceoff between ideological commitments to promoting work and states' desires to maximize protection against QC sanctions, the latter won overwhelmingly, with FNS's acquiescence.

Antihunger advocates saw this trend as both a serious harm in its own right and a grave threat to SNAP's stability and survival. AFDC had been dissolved in large part because it became associated with nonwork. Just as nobody cared that deliberate Reagan administration policies were the reason AFDC lacked substantial numbers of working recipients, nobody likely would care that SNAP's dwindling working poor participation was a byproduct of overzealous error-reduction efforts.

Because the existing QC system did indeed make households with complex or changeable circumstances greater error risks, states could be expected to impose burdensome requirements on working poor households - either to discourage their participation outright ${ }^{41}$ or at least to minimize the risk of errors. Unless QC's error measurement could be adjusted to reflect the degree of difficulty of states' caseloads or states' QC anxieties could be largely laid to rest, burdensome requirements were likely to become standard. Advocates successfully lobbied OMB and the White House to direct FNS to implement a series of QC and programmatic changes to

397 C.F.R. $\$ 273 \cdot 10(\mathrm{f})(4)-(5)(1998)$.

$4^{\circ}$ The author was general counsel at CBPP during this period.

${ }^{41}$ See David A. Super, Offering an Invisible Hand: The Rise of the Personal Choice Model for Rationing Public Benefits, 113 YALE L. J. 815 (2004). 
remove the bullseye from the backs of working households. With President Clinton seeking to pivot from his impeachment to establishing a legacy, he embraced the opportunity to announce a package of initiatives to help working poor households receive food assistance. The Clinton Food Stamp Initiative of July 14, 1999, allowed states to liberalize the rules for households to own motor vehicles while receiving SNAP, reduced reporting obligations for working poor households (which had the effect of preventing many routine changes in circumstances from causing inadvertent errors), and moderated the QC system. The initiative and follow-on action that September established a formula for waiving QC sanctions that likely resulted from serving larger numbers of working families. States' error rates were recomputed for three subpopulations - working households with children, households with immigrant members, ${ }^{42}$ and all others - with states' sanctions adjusted downward to reflect that share of the states' overall error rates resulting from disproportionate numbers of error-prone households. In addition, the tolerance for small errors was updated for inflation so that a recipient having a single extra work shift in a month would not be enough to cause an error.

The transformation in state attitudes was immediate and dramatic. The only states left with substantial QC sanctions were ones that undeniably did have serious problems with their programs' administration. These states had benefited from the united front of states sanctioned or at risk of sanctions, but now they had to face the realities of their own problems. Responding to the new priorities that the Clinton Initiative established, FNS offered these states plans under which part of their sanctions could be "reinvested" in improvements to program administration and part could be held "at risk," to be paid if the state's error rate remains high but waived if the state achieves significant progress. The "at risk" device sought to give human services administrators leverage with their state budget officers, governors, and legislatures to secure funding for more adequate staffing of SNAP eligibility determination. It often proved successful, allowing further reduction in error rates and thinning the ranks of states with seriously high error rates.

So rapid and complete was the change in state attitudes that states largely yawned in spring 2000 when FNS released the largest package of proposed SNAP regulatory changes in more than two decades. Along with changes required by the 1996 welfare law and those needed to codify the Clinton Food Stamp Initiative, this package included sweeping rollbacks of long-standing program access provisions. FNS had developed this package with state administrators in the mid-199os as the culmination of the effort to reduce states' workloads and tighten access for potentially error-prone cases. It had languished in USDA's glacial clearance process and eventually been combined with the proposed rules to implement the 1996 welfare law.

$4^{2}$ Although their modest numbers made them relatively small drivers in most states' error rates, the complexity of post-1996 eligibility rules for households containing immigrant members resulted in unusually large error rates for these households as well. 
A handful of states submitted tepidly supportive comments and a few more raised minor technical quibbles. By contrast, antihunger advocates reacted with outrage that the Clinton administration was considering these changes while SNAP enrollment was already plummeting. Hundreds of comments, some exceeding one hundred pages, attacked the proposed regulations. Antihunger groups pressed Secretary of Agriculture Dan Glickman and senior OMB and Domestic Policy Council officials to intervene. Although former governor Clinton's White House always had an open door to representatives of state governments, no pressure in support of the proposed rules emerged. In the end, Les Cash's successor guided a thorough rewrite of the proposed rules to eliminate virtually all access-restricting provisions. Instead, the final rules further relaxed accounting pressures on working poor households and, correspondingly, potential QC errors for states. ${ }^{43}$ State administrators' enthusiasm over these provisions swamped any disappointment over the rejection of the proposals they had negotiated with FNS at the height of the QC crisis.

Both antihunger advocates and state administrators wondered what George W. Bush's election would mean for the new federal-state détente in SNAP. They were relieved when he brought his human services commissioner from Texas, Eric Bost, to Washington to become USDA's undersecretary for food assistance programs. Although Texas had achieved very low error rates by driving working poor families off SNAP with three-month certification periods, Bost had previously served in other states and empathized with administrators facing QC sanctions. Using his knowledge of the program, his direct access to the president, and his considerable political skills, Bost persuaded the Bush administration to propose codification and expansion of some of the key Clinton program access initiatives and signed off on statutory QC reforms that were roughly the equivalent of what the Clinton administration had done administratively. Although improper denials and terminations remained outside the payment error rate on which sanctions were based, the legislation created a pool of bonus funds for states with outstanding performance in avoiding incorrect negative actions as well as for those that achieved high rates of timely application processing and participation among eligible households. ${ }^{44}$ When this legislation passed with broad bipartisan support, states could feel confident that a new consensus had emerged to balance concern with payment accuracy and program access. ${ }^{45}$

43 A QC error is defined as a substantial divergence between the benefits that should have been paid, if any, and the amount that were paid due to a violation of program rules by either the state agency or the household. If the program rules require fewer reports from households, fewer violations of reporting rules are possible.

447 U.S.C. $\$ 2025$ (d) (2016).

45 David A. Super, The Quiet "Welfare" Revolution: Resurrecting the Food Stamp Program in the Wake of the 1996 Welfare Law, 79 N.Y.U. L. Rev. 1271 (2004). 
The end of the QC wars led to a rapid, widespread acceptance of state options to improve access to low-wage workers. ${ }^{46}$ Within a few years, almost every state was allowing working families to report on their circumstances only once every six months. Three-month certification periods largely vanished except for households genuinely expected to leave the area almost immediately. All but a handful of states stopped counting the value of motor vehicles as assets in determining SNAP eligibility, using either "broad-based categorical eligibility" 47 or another option that Representative Jim Walsh (R-NY) quietly added through an appropriations bill in 2000. Many adopted options to provide transitional SNAP benefits to people leaving welfare for work.

Indeed, even in the midst of the QC conflict and the philosophical upheaval that the 1996 welfare law occasioned, states continued to seek to maximize federal SNAP funding in ways that would not adversely affect their error rates. Only a small handful adopted various options the welfare law provided to expand disqualifications of otherwise eligible low-income people. ${ }^{4}$ And after some initial skittishness, all but one state requested that their high-unemployment areas be waived ${ }^{49}$ from the welfare law's three-month time limit on childless adults. ${ }^{50}$ Indeed, most states had become such reliable SNAP maximizers that antihunger advocates relied on state options to eliminate counterproductive rules that were politically entrenched federally.

States' fund-maximizing largely represents a convergence of the humanitarian and elite efficiency-oriented perspectives on SNAP. The prospect of draconian QC penalties fractured that alliance for a time, but the alliance quickly reemerged with the end of overzealous QC enforcement. Groups that might have exploited that split lacked sufficient focus on SNAP: those advocating a disciplinary approach in prior

46 Program Design Branch, Food and Nutrition Service, USDa, Food Stamp Program State Options Report at 1-8 (4th ed. Sept. 2004) https://fns-prod.azureedge.net/sites/default/ files/snap/4-State_Options.pdf.

47 The 1996 welfare law preserved a long-standing feature of SNAP law, "categorical eligibility," that eliminated the usual asset test for households in which all members received benefits under Title IV-A of the Social Security Act, which previously had contained AFDC and now housed the TANF block grant. 7 U.S.C. \$2014(a) (2016). Under AFDC, benefits generally meant a monthly cash assistance check for which eligibility depended on meeting an even more stringent asset test. TANF, however, allowed states to provide many other kinds of benefits without an asset test. Under "broad-based categorical eligibility," a state can give all members of a household access to an inexpensive service and treat the household as categorically eligible for SNAP as a result. Antihunger advocates had pointed out this opportunity to states in 1998, and FNS acknowledged its validity in its 2000 regulations, but many states delayed implementing until they were confident that USDA would continue to recognize this option.

$4^{8}$ State Options Report, supra, at 18-21.

49 Ed Bolen \& Stacy Dean, Ctr. on Budget \& Pol'y Priorities, Waivers Add Key State Flexibility to SNAP's Three-Month Time Limit (Feb. 6, 2018) www.cbpp.org/research/ food-assistance/waivers-add-key-state-flexibility-to-snaps-three-month-time-limit.

50 7 U.S.C. \2015(o) (2016). 
decades had become deeply marginalized by the 1990s, and, although right-wing ideological opponents of antipoverty programs were becoming active in states, their primary focus was still on cash assistance funded under the Temporary Assistance for Needy Families (TANF) block grant that replaced AFDC.

\section{STATES AS IDEOLOGICAL BATTLEGROUNDS}

Responses to poverty combine practical and symbolic aspects. This has long been true of AFDC, which has served for some as a symbol of American generosity and for others as a monument to changing social norms. As open embraces of white supremacy became socially unacceptable, attacks on "welfare" served as a popular substitute. The result of symbolic political battles over AFDC was the program's decay and ultimate dissolution. The same uneasy partnership between practical and symbolic qualities exists in private charity as well: the stampede of volunteers seeking to help cook Thanksgiving dinner for the homeless is all about the symbolism of giving; the charities' struggles to ration grossly inadequate resources among myriad desperate applicants are typically guided by practical considerations.

State SNAP policy historically has been driven almost entirely by practical concerns, benign or otherwise. Those seeking to make symbolic or ideological points have focused on cash assistance, federal policy makers, or both. Over the past decade, however, that has changed dramatically. Progressive ideologues' attention remains fixed elsewhere, chiefly on enacting a single-payer health care system. Conservative ideologues, however, have begun to engage enthusiastically with state SNAP policy. This movement has provided a powerful counterpoint to the longstanding priority of maximizing federal funds.

This shift has several sources. Partly it reflects the radicalization of the Republican Party. Although many prominent Republicans - Richard Nixon, Bob Dole, Rudy Boschwitz, Bill Emerson, Richard Lugar, Saxby Chambliss, and Thad Cochran, among others - helped build and defend SNAP, today's Republican Party has forgotten or disparaged them. Even though a Republican president sent Congress a package of SNAP eligibility and benefit expansions as recently as 2002, support for antipoverty programs appears no longer to lie within the acceptable range of Republican thought..$^{51}$

The shift from maximizing federal funds to maximizing ideological purity also reflects similar changes in other areas of antipoverty policy. Several Republican governors rejected welfare-to-work grants that bipartisan federal legislation created in 1997 despite the fit with the goals those governors were espousing. Resistance to the bipartisan No Child Left Behind Act similarly privileged states' rights ideology over receipt of federal education funds. And on a much grander scale, Republican states'

${ }^{51}$ Indeed, had Senator Cochran not recently retired, the author would have omitted him from this list to avoid embarrassing him politically. 
refusal to accept the Affordable Care Act's Medicaid expansion, and refusal to establish state health insurance exchanges, sacrificed billions of dollars that would have benefited politically powerful hospitals and doctors..$^{52}$ Voluntarily reducing the flow of federal funds by operating a miserly version of SNAP is far less costly.

Perhaps the most significant reason state SNAP policy has become so ideological is the rapid growth of funding for right-wing state advocacy. A few states have long had conservative policy groups, but these were relatively small and only occasionally engaged seriously with antipoverty policy. Washington-based conservative advocacy groups such as the Heritage Foundation, the American Enterprise Institute, and the Cato Institute occasionally tried to influence state policy, but this often consisted only of issuing national reports or responding to specific requests in states.

All that changed with rise of ALEC. ALEC is well known for feeding model bills to conservative state legislators such as the "stand your ground" law that helped acquit Trayvon Martin's killer. ALEC meetings also provide a vehicle for connecting conservative donors with state-oriented advocacy groups. In addition to ALEC, which has steadily increased its opposition to antipoverty programs, state policy makers increasingly hear from the Secretaries' Innovation Group (SIG) and the Foundation for Government Accountability (FGA). SIG is an organization of rightwing former human services administrators; FGA broadly seeks to reduce eligibility and benefits in antipoverty programs. Although each remains hostile to programs under the TANF block grant, so few people remain on cash assistance, ${ }^{53}$ and states' policies are already so restrictive, that it has lost appeal even as a symbolic target.

Right-wing advocacy groups' agendas typically lack unifying principles except reducing eligibility for SNAP and portraying SNAP recipients negatively. These groups are not, for example, pursuing the kind of "prowork" agenda that prior conservatives claimed: FGA advocates disqualifying otherwise eligible people who cannot find jobs for enough hours, but it also pushes to disqualify low-wage workers based on the value of the cars they drive to work. Even the Heritage Foundation's Robert Rector, by far the most important outside influence in shaping the 1996 welfare law's massive benefit cuts, found parts of FGA's agenda excessive. ${ }^{54}$

Many of their proposals seek to weaken public support for SNAP by implying serious moral deficiencies in low-income people without any serious evidence. 55

52 See David A. Super, The Modernization of American Public Law: Health Care Reform and Popular Constitutionalism, 66 Stan. L. Rev. 873 (2014).

53 Ife Floyd et al., Ctr. on Budget \& Pol'y Priorities, tanf Reaching Few Poor FAmilies (rev. Dec. 13, 2017), www.cbpp.org/research/family-income-support/tanf-reachingfew-poor-families.

54 Robert Rector et al., Heritage Foundation, Five Steps Congress Can Take to Encourage Work in the Food Stamps Program (Apr. 19, 2018), www.heritage.org/ hunger-and-food-programs/report/five-steps-congress-can-take-encourage-work-the-food-stampsprogram.

55 See David A. Super, The New Moralizers: Transforming the Conservative Legal Agenda, 104 Colum. L. Rev. 2032 (2004). 
They demand that applicants be drug tested despite the lack of evidence of disproportionate substance abuse by SNAP recipients - and insufficient treatment facilities for most. Similarly, despite USDA studies showing low fraud in SNAP, ${ }^{6}$ these groups demand aggressive, and loudly stigmatizing, antifraud campaigns. Ignoring evidence that low-income shoppers obtain more nutrients per food dollar spent than any other income group, FGA champions obesity-themed food purchasing restrictions. Similarly, FGA advocates finger-printing recipients even though several states' experience with finger imaging was so thoroughly cost-ineffective that FNS no longer allows federal matching funds for such contracts. ${ }^{57}$ Another stigmatizing proposal without practical potential would require SNAP recipients to have photographic identification cards: these serve no practical purpose as retailers cannot require persons to present such cards because federal regulations allow households to authorize representatives to buy food for them. ${ }^{8}$ Capitalizing on stigmatization of overweight persons and ignoring research evidence that SNAP recipients obtain more nutrients per food dollar spent, they advocate restrictions on what SNAP benefits may purchase, which would lead to many humiliating interactions at checkout lines.

These groups' top priority, however, has been enacting state laws prohibiting human services agencies from seeking waivers from the three-month time limit that the 1996 welfare law imposed on many childless adults between the ages of 18 and 50. Although this provision's sponsors misleadingly characterized it as a "work requirement," it disqualifies individuals without regard to how much effort she or he has made to find work or how willing she or he is to perform unpaid work in exchange for continued SNAP eligibility. As noted previously, the statute allows states to request waivers from this requirement for areas with "insufficient jobs," and in the late 199os all but one state sought at least some waivers. Conservative groups have won enactment of legislation in several states prohibiting such waivers and have persuaded several additional governors to forbid their human services agencies from requesting them. Notably, despite the prowork rhetoric of ALEC, FGA, and SIG, none has made any discernible effort to press states to offer work slots to all recipients facing termination under the time limit despite the additional federal E\&T funding available to states that do so. ${ }^{59}$

${ }^{56}$ Joseph Willey et al., Food \& Nutrition Service, USDA, The Extent of Trafficking in the Supplemental Nutrition Assistance Program: 2012-2014, at 12 (2017).

57 Here the business interests that fund much right-wing state-level advocacy might be playing a role: companies selling finger-printing services in the private market can boast of larger "libraries" if they have collected the fingerprints of millions of SNAP recipients.

$5^{8} 7$ C.F.R. $\int 273.2(\mathrm{n})(3)$ (2018). Here broader Republican political priorities may play a role. A recurrent objection to state laws requiring voters to present photographic identification at the polls is that many low-income voters lack such identification; this argument can be blunted if the state issues identity cards to many low-income people through SNAP.

597 U.S.C. $\$ 2025(\mathrm{~h})(1)(2016)$. 
Although these policies could be mistaken for a reemergence of the model that sees the states as disciplinarians of the poor, they differ in both purpose and content. Agricultural employers wanted a large workforce that would depress wages. They thus saw an advantage in having meager programs to allow low-skilled workers to remain in the area when not needed on the farms. Current ideologues make no such distinctions, supporting any policy reducing benefits or stigmatizing recipients that seems to have potential political appeal. Indeed, ALEC's and FGA's top priority has been denying SNAP specifically to people in areas of high unemployment by blocking time-limit waivers there.

The new ideological approach to state SNAP policy is better understood as part of the same agenda of distraction and diversion that has produced fiercely antiimmigrant policies, a budding trade war, and frightening rhetoric about nonexistent crime waves. Condemning low-income people as morally unworthy may be the only viable strategy for deflecting criticism of fast-rising income inequality. Politicizing SNAP also provides Tocquevillian opportunities to develop right-wing civic virtues by practicing advocacy against antipoverty programs at the state and local level, making participants more reliable supporters of similar national efforts.

\section{THE WAY FORWARD}

For the foreseeable future, the tension between fund maximization and right-wing opposition to antipoverty programs is likely to shape states' roles in SNAP. However incoherent conservative proposals may be, attacks on antipoverty programs have proven political power, and the vast quantities of right-wing funds seeking activism to support will ensure that these positions will keep coming back.

On the other side, the forces that inclined states to seek to maximize SNAP federal funding - first and foremost for themselves, but also for low-income households have weakened significantly in recent years. The generation of senior state administrators that remembers SNAP's early days, and that responded at least to the afterglow of the War on Poverty, have now left the scene. Many were pushed out prematurely in the conflict over error rates and were hence discredited with their successors. Those that survived the QC wars largely accepted the retirement incentives states offered to shrink their workforces during the Great Recession. In place of these administrators is a far more technocratic generation hired to reduce error rates and implement automated eligibility determination systems. Some are professional managers with little or no background in social work or experience working with low-income people.

State human services agencies have changed even more dramatically on their lower levels. Although social work-trained eligibility workers disappeared in most states long ago, eligibility workers at least had routine contact with SNAP recipients. Many, although by no means all, developed genuine empathy from these contacts. That model, however, is fast disappearing. The Great Recession simultaneously devastated state budgets, forcing large reductions in human services agencies' staffs 
and dramatically increased the number of households seeking SNAP. The traditional model assumed individual eligibility workers would serve caseloads of up to two hundred households; in numerous states, eligibility workers' caseloads far exceeded one thousand. The clear political infeasibility of securing the necessary resources from governors and legislatures caused human services administrators to go all-in on technology. Eligibility workers were herded into gigantic call centers where they would receive and process households' reports of changed circumstances, interview applicants and recipients over the phone, examine verification documents scanned in at kiosks in local communities - and rarely speak with the same household twice. Where politics precluded closing local human services offices, states established "statewide caseloads" that enabled eligibility workers to make changes in the benefits of a household living on the other end of the state. Eliminating continuing relationships between individual workers and recipient households inevitably reduces empathetic voices within state agencies. Indeed, right-wing groups continue to advocate for moving large parts of SNAP administration out of state agencies altogether, even though the Bush administration's two major attempts to privatize both ended in disaster. ${ }^{60}$

State government organizations that historically served a moderating function also are badly weakened. ALEC has pressed legislators to support it in preference to the bipartisan National Conference of State Legislatures, eroding the latter's funding and undercutting its claims to speak for state legislatures broadly. SIG has sought to weaken the American Public Human Services Association (APHSA) similarly. Hardline Republicans have blocked the National Conference of State Legislatures (NCSL), APHSA, and the National Governors Association from taking positions on numerous current public benefits issues important to states. Although the resulting dysfunction is most obvious in federal policy debates, it also has weakened policy coordination among states.

Rising inequality has fractured market after market, with some providers serving middle- and upper-income communities and others operating in low-income areas. Thus, many large businesses with broad political influence no longer receive significant business from low-income people. Trade associations of landlords, food stores, child care providers, and the like therefore may see the recipients of public benefits as outside their customer bases. ${ }^{61}$

Nonetheless, maximizing federal funds remains the dominant theme for most states. This can be seen in the opposition of many states to President Trump's proposals to require a state match for SNAP benefit costs and in states' general disinterest in House Republicans' various proposals to cap or block-grant SNAP spending. Of course, in a prior era one might imagine a bipartisan outcry from states

60 David A. Super, Privatization, Policy Paralysis, and the Poor, 96 Calif. L. Rev. 393, 395 (2008).

61 See David A. Super, The Rise and Fall of the Implied Warranty of Habitability, 99 CaLiF.

L. REv. $3^{89}$ (2011) (describing changes in the low-income housing market). 
over the administrative burdens of redetermining households' eligibility monthly and having to provide work programs for millions of people, as the House of Representatives' 2018 farm bill would require. ${ }^{62}$

Ironically, QC now constrains states' shift to ideological SNAP policy making. Right-wing governors are deterred from hiring conservative zealots lacking governmental experience by the danger that mismanagement will result in costly and embarrassing fiscal sanctions. Ideologically motivated privatization plans in Texas and Indiana, and aggressively harsh administration in Wisconsin, all resulted in ballooning error rates and fiscal sanctions. In many states, governors and legislatures may make ideological high-level SNAP policy decisions while technocratic SNAP directors continue pursuing fund maximization on lower-profile matters. This does mean, however, that creating state options to moderate harsh policies will have decreasing value as a compromise in federal policy making.

One recent episode illustrates both the continued draw of the fund-maximizing approach and the durability of the relationship between federal and state SNAP administrators. The USDA Inspector General attacked some states for manipulating sampling procedures to reduce their error rates. ${ }^{\sigma_{3}}$ The prospect of reigniting the QC wars was sufficiently repellent to all concerned that FNS and state administrators worked cooperatively in revising procedures to address these concerns. Whether similar cooperation remains possible on higher-profile issues is very much in doubt.

The demise of the disciplinarian model and the weakening of the fund maximization model of state SNAP are the result of shifts in the power of various interest groups and in the extent of their attention to SNAP. Further shifts are inevitable. If ongoing changes in the economics of food retailing cause large, powerful corporations to see low-income people as part of their consumer bases, the fund maximization model may revive. If President Trump moves the country sharply to the right, progressives may become even more distracted defending other laws and programs and leave SNAP policy increasingly to right-wing ideologues. If, by contrast, the country swings left in reaction to President Trump and Congress enacts a single-payor health insurance plan, perhaps hunger will become a major new priority for progressives and they may come to dominate state SNAP policy making. Other groups that have not traditionally been active in state SNAP policy making could well emerge.

The long-standing assumption that states played little meaningful role in make SNAP policy was never true. With the range of groups that have sought to shape state SNAP policies over the past several decades, states' roles are now gaining much wider recognition. We can and should judge the political and moral climate of a state by how it treats those struggling to secure enough food.

${ }^{62}$ David A. Super, The New Republican Farm Bill Will Dismantle Our Programs to Feed the Needy, L.A. Times, May 11, 2018, www.latimes.com/opinion/op-ed/la-oe-super-farm-bill-snap20180511-story.html.

63 Office of Inspector General, FNS Quality Control Process for SNAP Error Rate (Audit Report 27601-0002-41 Sept. 13, 2015), www.usda.gov/oig/webdocs/276o1-ooo2-41.pdf. 